\title{
UJI PENERIMAAN KONSUMEN TERHADAP CITA RASA IKAN BANDENG (Chanos chanos Forsskal) DARI BEBERAPA LOKASI BUDIDAYA DI INDONESIA
}

\author{
Ahmad Thalib $^{1^{*}}$, Titis Istiqomah ${ }^{2}$, Bhiaztika Ristyanadi $^{3}$, Nanuk Qomariyati ${ }^{3}$ \\ ${ }^{1}$ Program Studi Teknologi Hasil Perikanan, Fakultas Pertanian Universitas \\ Muhammadiyah Maluku Utara, Ternate \\ ${ }^{2}$ Program Studi Manajemen, Fakultas Ekonomi Universitas Nahdlatul Ulama Sidoarjo \\ ${ }^{3}$ Program Studi Agribisnis, Fakultas Perikanan Universitas Islam Lamongan \\ *Email author: madoks75@yahoo.co.id
}

\begin{abstract}
ABSTRAK
Ikan bandeng merupakan jenis ikan air payau yang sangat disukai oleh masyarakat Indonesia. Cita rasa daging ikan bandeng ditengarai berbeda-beda sesuai dengan perairan asal usul tempat budidayanya. Penelitian bertujuan menguji cita rasa bandeng yang diperoleh dari beberapa perairan yang berbeda dengan penguji yang sama. Metode penelitian deskriptif dengan pendekatan uji sensoris melalui perangkat tes organoleptik. Hasil uji menunjukkan bahwa setiap lokasi asal usul budidaya memiliki nilai cita rasa yang tinggi bagi masing-masing penguji nya. Ikan bandeng asal Sidoarjo nilai rata-rata 7,8 dianggap memiliki cita rasa sedikit lebih tinggi dibandingkan dengan ikan bandeng Cirebon, Juwana, Demak, Maros, Ternate, Halmahera Barat, Pasuruan, Kota Baru, Banyuwangi, dan Takalar dengan nilai rata-rata pada kisaran 7,4 sampai dengan 7,7; sedangkan ikan bandeng asal Gresik dan Lamongan memiliki nilai rata-rata terendah 7,2 dan 7,1 .
\end{abstract}

Kata kunci: ikan bandeng, cita rasa, uji sensoris

\section{PENDAHULUAN}

Produksi ikan bandeng dijumpai di berbagai wilayah perairan payau di seluruh Indonesia. Beberapa kota bahkan menggunakan ikan ini sebagai ikon produk unggulan seperti halnya di Sidoarjo dan Cirebon. Produksi ikan bandeng terbukti juga sangat digemari oleh konsumen diluar pulau Jawa seperti: Maluku Utara, Sulawesi Selatan, Kalimantan Timur, Jawa Timur dan berbagai provinsi lain di Indonesia.

Ikan ini merupakan jenis ikan air payau yang mampu tumbuh berkembang dengan baik pada perairan tawar (0 permil) hingga tambak di pesisir dengan salinitas yang tinggi (35 permil). Sifat makan ikan adalah herbivora dan lebih dikenal sebagai pemakan plankton (plankton feeder). Melalui sifatnya mencari makanan inilah; maka ikan bandeng cenderung memiliki cita rasa yang agak berbeda-beda sesuai dengan karakteristik lokasi budidaya.

Ikan merupakan produk yang cepat membusuk; hal mana batas kesegaran ikan dan pembusukan ditandai dengan fase rigor mortis (Datta, 2013). Pada saat fase rigor mortis terjadi perubahan nilai nutrisi (Tilami and Sampels. 2017); dan mengakibatkan terjadinya perubahan bau dan cita rasa. Laju terjadinya rigor mortis berbedabeda setiap ikan; jenis ikan bandeng merupakan jenis yang cukup lama bertahan kesegarannya sebelum memasuki fase rigor mortis sehingga kualitas kesegarannya dapat dipertahankan dalam waktu yang lebih 
panjang.

Permasalahan mendasar yang membedakan cita rasa ikan bandeng adalah adanya bau lumpur (bau tanah) pada daging ikan saat dikonsumsi. Ikan bandeng yang dibudidayakan di kolam dan tambak air tawar memiliki kecenderungan kuat memiliki bau tanah pada dagingnya. Demikian halnya dengan ikan bandeng yang dibudidayakan polikultur dengan padi atau lebih dikenal dengan sawah tambak. Banyak pihak menduga bahwa efek pemupukan (kimia anorganik) merupakan pemicu timbulnya bau tanah. Ikan bandeng sebagai jenis pemakan plankton memiliki sifat mengaduk tanah dasar perairan untuk mencari plankton sebagai makanannya. Tanah dasar perairan yang cenderung berpasir yang diaduk oleh ikan akan terangkat dan membuat air di sekitarnya menjadi keruh; pada saat inilah plankton tersebar melayang di air sehingga mudah disantap oleh mulut ikan. Penelitian Erungan (1997) melaporkan bahwa penyebab cita rasa lumpur pada ikan bandeng adalah geosmin yang dihasilkan dari metabolisme ganggang alga hijau biru jenis Oscillatoria sp., Lyngbia sp., dan Symloca sp. .

Konsumen ikan bandeng untuk konsumsi mayoritas adalah masyarakat Indonesia. Ekspor untuk konsumsi ke Jepang misalnya; hampir tidak ditemukan kecuali ekspor ikan bandeng untuk pancing ikan tuna. Ikan ini tidak digemari untuk konsumsi di Jepang karena dianggap berbahaya akibat kandungan duri ikan yang banyak. Salitus, dkk. (2017) menjelaskan bahwa upaya untuk mempermudah masyarakat meng konsumsi ikan bandeng dikembangkan dengan penerapan teknik cabut duri; agar konsumen tidak lagi takut terkena duri saat makan daging ikan.

Ekspor ikan bandeng untuk konsumsi ke negara Timur Tengah, Eropa dan Asia lainnya umumnya juga ditujukan untuk memenuhi kebutuhan konsumsi bagi mayoritas masyarakat Indonesia, atau masyarakat penggemar ikan bandeng dari negara Asia yang tinggal di luar negeri (Eropa dan Timur Tengah). Ukuran ikan bandeng yang diekspor untuk konsumsi juga ikan yang besar dengan berat per ekor terendah 300 gram hingga 800 gram atau lebih. Berbeda dengan ekspor ikan bandeng untuk umpan pancing ikan tuna berukuran 100 gram sampai 250 gram per ekor; dengan syarat tambahan utama yaitu: sisik utuh dan mengkilat, mata bening, dan segar (agar tekstur tetap kenyal pada saat thawing).

Penelitian bertujuan untuk menguji cita rasa ikan bandeng yang diperoleh dari beberapa perairan yang berbeda dengan penguji yang sama.

\section{METODE PENELITIAN}

\section{Tempat dan Waktu Pelaksanaan}

Penelitian dilakukan di Ternate, Sidoarjo dan Lamongan yang merupakan domisili para tim peneliti. Waktu pelaksanaan uji sensoris adalah bulan Juni 2019. Batasan waktu penelitian selama bulan Juni dimaksudkan untuk memperoleh sampel ikan bandeng segar beku dari berbagai daerah penghasil ikan bandeng di Indonesia pada masa budidaya yang sama.

\section{Populasi dan Sampel}

Populasi adalah petambak ikan bandeng dari beberapa wilayah yang dapat diakses oleh tim peneliti untuk mendatangkan ikan sesuai dengan kriteria yang diminta oleh tim peneliti melalui beberapa cara yang berbedabeda. Asal usul ikan bandeng berasal dari tambak di (1) Ternate, (2) Halmahera Barat, (3) Maros, (4) Takalar, (5) Kota Baru / Pulau Laut, (6) Cirebon, (7) Demak, (8) Juwana, (9) Lamongan, (10) Gresik, (11) Sidoarjo, (12) Bangil Pasuruan. Sampel penelitian adalah ikan 
bandeng dari hasil budidaya tambak polikultur tradisional antara ikan bandeng dan udang; atau ikan bandeng + udang + padi; atau ikan bandeng + udang + rumput laut. Kondisi ikan yang diterima oleh tim peneliti dalam kondisi segar beku sebelum tiba saat pelaksanaan uji sensoris yang dilaksanakan secara serentak.

Sampel ikan bandeng yang diteliti harus memenuhi kriteria:

1) Size ikan $300 \mathrm{~s} / \mathrm{d} 400$ gram per ekor (ukuran konsumsi);

2) Dipanen dari tambak dalam kondisi hidup (dengan jala atau serok);

3) Sesaat setelah diangkat dari perairan habitat hidupnya langsung dimasukkan ke dalam air es dengan suhu $3^{\circ}-5^{\circ} \mathrm{C}$; agar ikan mati dalam kondisi tercekik akibat hipotermia;

4) Ikan yang tercekik dalam kondisi kaku langsung dimasukkan ke dalam badan pembeku (freezer) minus $15^{\circ} \mathrm{C}$ selama 24 s/d 72 jam kemudian dikirim ke masing-masing lokasi penelitian dengan menggunakan styrofoam dan dry ice; dengan memanfaatkan sistem transportasi yang ada (paket darat dan udara);

5) Pengujian dilakukan dengan dua cara yaitu: dicairkan - disiangi dikukus (steam); dan dicairkan disiangi - digoreng dengan minyak goreng ' $\mathrm{X}$ ' merek yang sama serta cara penggorengan yang sama;

6) Uji cita rasa disajikan secara acak dengan menggunakan kode penelitian yang diketahui oleh tim peneliti. Masing-masing anggota tim menguji sampel terhadap 20 panelis.

\section{Metode Analisis}

Metode penelitian deskriptif dengan pendekatan uji sensoris melalui perangkat tes organoleptik terhadap cita rasa, bau, warna, penampakan, konsistensi, dan nilai estetika ikan. Peralatan tes pada lokasi penelitian yang berbeda menggunakan juklak teknis penyajian yang sama bagi para panelis di mana pun berada, antara lain:

1) Pengukusan menggunakan alat kukus yang sama (merek, bahan dan volumenya); pada takaran air dan suhu serta lama proses pengukusan yang sama, sesuai dengan kesepakatan para tim peneliti. Demikian pula dengan penggorengan menggunakan perangkat penggoreng teflon dan minyak goreng yang merek nya ' $X$ ' sama;

2) Ikan kukus maupun goreng merupakan potongan dalam bentuk drawn with bone dengan pisau stainless tajam sesuai bentuk harakami toro dan sekami toro pada ikan bandeng. Tidak dibedakan bagian kiri dan bagian kanan dari tubuh ikan. Dasar pemilihan bagian harakami toro dan sekami toro sebagai bagian daging ikan bandeng yang diuji cita rasanya adalah: merupakan bagian daging ikan yang terdapat pada punggung (dorsal) dan perut (ventral) yang terdekat dengan sistem pencernaan ikan; sehingga apabila terjadi penetrasi senyawa tertentu yang membuat daging ikan bercita rasa menyimpang (bau lumpur) maka daging pada bagian inilah yang paling cepat dan paling banyak terpengaruh;

3) Bagian yang diuji diletakkan pada kertas kue pada ruangan ber $\mathrm{AC}$ dengan suhu ruangan $25^{\circ}-27^{\circ} \mathrm{C}$;

4) Panelis diminta mengambil bagian yang sama pada setiap sampel yang tersedia dan memberikan skor pada kartu skor yang disediakan;

5) Untuk homogenisasi cita rasa pada lidah digunakan potongan roti tawar ukuran $3 \times 3 \times 1 \mathrm{~cm}$ dan air minum dalam kemasan merek ' $X$ ' yang sama; sedangkan pada hidung digunakan setengah lembar tissue basah merek ' $\mathrm{X}$ ' yang sama dibilas dengan tissue kering merek ' $\mathrm{X}$ ' yang sama pula;

6) Panelis melakukan pengujian 
bergiliran dan berurutan; tidak diperkenankan melakukan uji pada saat yang bersamaan terhadap satu kode pengamatan.

\section{Teknik Penilaian}

Standarisasi pendapat subyektif cita rasa dilakukan dengan cara menyusun peringkat pendapat pada skala 1 - 10 melalui penilaian terbuka dan tertutup. Dipilihnya rentang skala 1 - 10 bertujuan untuk memperoleh pendapat yang lebih rinci dan spesifik mengenai cita rasa ikan bandeng; hal merupakan keniscayaan yang harus dilakukan mengingat selera (lidah) manusia dipengaruhi oleh cita rasa makanan sehari-hari di tempat asalnya masing-masing. Standarisasi pendapat subyektif diperoleh untuk membuat kesepakatan umum mengenai skala cita rasa dari yang paling buruk (sangat tidak enak) hingga paling enak (amat sangat enak). Mchazime and Kapute (2018) menegaskan bahwa dalam kurun waktu 6 jam setelah perlakuan; sampel yang diuji secara organoleptik memiliki cita rasa yang belum berubah.

Penilaian terbuka dituliskan panelis langsung pada score sheet sesaat setelah mengamati secara sensoris daging ikan bandeng kukus dan goreng. Penilaian tertutup dilakukan oleh tim peneliti berupa jajak pendapat untuk memperoleh komentar panelis terhadap masing-masing sampel yang diamati. Komentar diberi nilai oleh tim; dikompilasikan dengan hasil penilaian terbuka hingga diperoleh angka rata-rata sebagai skor akhir penilaian. Standar penilaian disajikan pada Tabel 1.

Tabel 1. Standar penilaian uji komparasi cita rasa ikan

\begin{tabular}{|c|c|c|}
\hline $\begin{array}{l}\text { Skor } \\
\text { Score }\end{array}$ & $\begin{array}{l}\text { Penilaian skor terbuka } \\
\text { Open scoring } \\
\text { assesment }\end{array}$ & $\begin{array}{l}\text { Penilaian skor tertutup } \\
\text { Special scoring assessment }\end{array}$ \\
\hline & $\begin{array}{l}\text { Indikator Nilai } \\
\text { Value indicator }\end{array}$ & $\begin{array}{l}\text { Indikator Komentar: Panelis menyatakan ............. } \\
\text { Comment indicator: panelists stated as ............ }\end{array}$ \\
\hline 10 & $\begin{array}{l}\text { Amat sangat enak } \\
\text { Very, very delicious }\end{array}$ & $\begin{array}{l}\text { Tidak dapat dilukiskan dengan kata-kata } \\
\text { Cannot be described in words } \\
\text { Kalau makan bakal nambah terus ............ } \\
\text { If you want to eat, keep adding }\end{array}$ \\
\hline 9 & $\begin{array}{l}\text { Sangat enak } \\
\text { Very delicious }\end{array}$ & $\begin{array}{l}\text { Gurih atau 'maknyus' } \\
\text { Tastefull or 'maknyus' }\end{array}$ \\
\hline 8 & $\begin{array}{l}\text { Benar-benar enak } \\
\text { Really delicious }\end{array}$ & $\begin{array}{l}\text { Lebih enak dibandingkan dengan ikan lain } \\
\text { Better than other fish }\end{array}$ \\
\hline 7 & $\begin{array}{l}\text { Enak } \\
\text { Delicious }\end{array}$ & $\begin{array}{l}\text { Saya suka, sering makan ikan bandeng } \\
\text { I like it, I often eat milkfish }\end{array}$ \\
\hline 6 & $\begin{array}{l}\text { Lumayan enak } \\
\text { Pretty good }\end{array}$ & $\begin{array}{l}\text { Lauk pilihan apabila ikan ini tersedia di meja makan } \\
\text { A side dish of choice if the fish is available at the } \\
\text { dining table }\end{array}$ \\
\hline 5 & Biasa saja Ordinary & $\begin{array}{l}\text { Enak, tapi kadang ada bau tanah } \\
\text { It's delicious, but sometimes there is a mud-smell }\end{array}$ \\
\hline 4 & Kurang enak Not tasted & $\begin{array}{l}\text { Bau lumpur pada daging cukup mengganggu } \\
\text { The smell of mud on the meat is quite disturbing }\end{array}$ \\
\hline 3 & $\begin{array}{l}\text { Agak tidak enak } \\
\text { Rather bad }\end{array}$ & $\begin{array}{l}\text { Kurang suka, jarang makan kecuali terpaksa } \\
\text { Dislike, rarely eat unless forced to }\end{array}$ \\
\hline 2 & $\begin{array}{l}\text { Tidak enak } \\
\text { Not good }\end{array}$ & $\begin{array}{l}\text { Tidak mau } \\
\text { Do not want }\end{array}$ \\
\hline & $\begin{array}{l}\text { Sangat tidak enak } \\
\text { Very bad }\end{array}$ & $\begin{array}{l}\text { Muntah !!!!! } \\
\text { Throw up }\end{array}$ \\
\hline
\end{tabular}




\section{HASIL DAN PEMBAHASAN}

\section{Teknik Budidaya di Beberapa Daerah}

Ikan bandeng yang diuji seluruhnya diperoleh dari hasil budidaya tambak secara tradisional pada masingmasing daerah asalnya; yang teknik budidaya menggunakan pola polikultur antara udang dan ikan bandeng. Tidak dibedakan jenis-jenis udang windu atau udang vanamei dengan dasar pemikiran bahwa masing-masing ikan dan udang tidak menggunakan pakan buatan apapun selama budidaya; sehingga cita rasa murni yang diharapkan pada saat uji sensoris adalah mencerminkan kondisi alami masing-masing perairan asal usul ikan bandeng. Budidaya ikan bandeng tradisional secara polikultur ternyata juga berbeda-beda di beberapa daerah. Budidaya polikultur tradisional di Ternate, Halmahera Barat, Maros, Takalar, Kota Baru, Cirebon, Demak, Juwana, Sidoarjo, Pasuruan dan Banyuwangi; mayoritas umumnya menggunakan tambak yang sumber airnya berasal dari sungai atau muara sungai di dekat laut, mengalami pengaruh pasang surut secara langsung, terdapat tanaman mangrove, dan masih banyak ditemukan polikultur dengan udang windu, yang merupakan udang asli Indonesia. Sedangkan di Gresik dan Lamongan; serta beberapa lokasi di Cirebon, Takalar dan Sidoarjo; dijumpai budidaya polikultur tradisional ikan bandeng di sawah tambak, bersama dengan tanaman padi dan udang vannamei.

Budidaya polikultur tradisional di Gresik dan Lamongan menggunakan sumber air utama dari aliran sungai Bengawan Solo dan relatif jauh dari laut; sehingga salinitas air cenderung rendah hingga tawar. Selain itu; pola budidaya di Gresik dan Lamongan masih lebih mengedepankan upaya untuk memperoleh hasil panen dari tanaman padi, sehingga petani tambak cenderung mengandalkan penggunaan pupuk kimia anorganik seperti Urea, TSP, dan ZA dalam takaran penggunaan yang lebih banyak dari dosis rekomendasi Pemerintah.

Dengan demikian, kesuburan tanah dan perairan di Gresik dan Lamongan terbentuk akibat proses pemupukan kimia anorganik meskipun pola pembudidayaan ikan bandeng itu sendiri pada dasarnya secara tradisional; sedangkan di daerah penelitian lainnya tidak demikian.

Ikan bandeng umumnya dipanen pada umur 3 - 5 bulan umur budidaya pada ukuran 300 - 400 gram per ekor; merupakan size konsumsi yang umum di pasaran. Dasar pemikiran bahwa ukuran tersebut merupakan size konsumsi adalah panjang ikan dianggap setara dengan panjang piring oval, pada saat penyajian ikan kepada konsumen untuk dinikmati bersama $2-3$ orang sebagaimana layaknya penjualan ikan bandeng olahan di rumah makan. Susanto dan Fahmi (2012) menyatakan pentingnya mengkonsumsi untuk mendapatkan asupan nutrisi yang bermutu bagi tubuh manusia.

\section{Uji Cita Rasa}

Hasil uji menunjukkan bahwa setiap lokasi asal usul budidaya memiliki nilai cita rasa yang tinggi bagi masing-masing penguji nya. Ikan bandeng asal Sidoarjo nilai rata-rata 7,8 dianggap memiliki cita rasa sedikit lebih tinggi dibandingkan dengan ikan bandeng Cirebon, Juwana, Demak, Maros, Ternate, Halmahera Barat, Pasuruan, Kota Baru, Banyuwangi, dan Takalar dengan nilai rata-rata pada kisaran 7,4 sampai dengan 7,7; sedangkan ikan bandeng asal Gresik dan Lamongan memiliki nilai rata-rata terendah 7,2 dan 7,1. Hasil penilaian panelis disusun secara acak dengan menggunakan kode telusur yang diketahui oleh tim peneliti; untuk membedakan asal usul panelis dan menekan bias perbedaan cita rasa 
masing-masing panelis sebagai interpretasi tingkat kesukaan konsumen dari tiga lokasi yang berbeda yaitu: Ternate, Sidoarjo, dan Lamongan. Hasil rata-rata penilaian disusun tertinggi hingga terendah, dengan gap skor ratarata disajikan pada Tabel 2 .

Tabel 2. Skor rata-rata uji cita rasa konsumen terhadap asal usul ikan bandeng

\begin{tabular}{|l|l|l|l|l|}
\hline \multirow{2}{*}{$\begin{array}{l}\text { Asal ikan The } \\
\text { origin of fish }\end{array}$} & \multicolumn{3}{|l|}{$\begin{array}{l}\text { Asal panelis penilai cita rasa } \\
\text { The origin of the appraisal panelists }\end{array}$} & $\begin{array}{l}\text { Rata-rata } \\
\text { seluruhnya } \\
\text { Overall average }\end{array}$ \\
\cline { 2 - 4 } & Ternate & Sidoarjo & Lamongan & 7,8 \\
\hline Sidoarjo & 7,8 & 7,6 & 8,0 & 7,7 \\
\hline Cirebon & 7,5 & 7,7 & 7,9 & 7,6 \\
\hline Juwana & 7,5 & 7,4 & 7,9 & 7,6 \\
\hline Demak & 7,5 & 7,4 & 7,9 & 7,6 \\
\hline Maros & 7,5 & 7,4 & 7,9 & 7,5 \\
\hline Takalar & 7,5 & 7,2 & 7,8 & 7,5 \\
\hline Pasuruan & 7,5 & 7,4 & 7,6 & 7,5 \\
\hline Kota Baru & 7,5 & 7,3 & 7,7 & 7,4 \\
\hline Banyuwangi & 7,5 & 7,1 & 7,6 & 7,4 \\
\hline Ternate & 7,3 & 7,3 & 7,6 & 7,4 \\
\hline $\begin{array}{l}\text { Halmahera } \\
\text { Barat }\end{array}$ & 7,3 & 7,3 & 7,6 & 7,2 \\
\hline Gresik & 7,3 & 7,0 & 7,3 & 7,1 \\
\hline Lamongan & 6,9 & 7,3 & 7,1 & \\
\hline
\end{tabular}

Rentang hasil penilaian yang menunjukkan cita rasa untuk masingmasing ikan bandeng dari berbagai wilayah tambak di Indonesia menunjukkan angka yang tipis 0,8 dari skala penilaian 1 - 10 . Hal ini menunjukkan bahwa daging ikan bandeng memiliki cita rasa yang tidak jauh berbeda pada lidah konsumen. Rentang rata-rata skor 0,7 berada pada kisaran 7,1 s/d 7,8; bahkan pada saat tes beberapa panelis memberikan nilai yang sama untuk asal usul yang berbeda.

Panelis di Lamongan, sangat menyukai ikan bandeng dibandingkan panelis di Ternate dan Sidoarjo. Skor rata-rata penilaian panelis Lamongan terhadap seluruh sampel yang diuji sebesar 7,68; lebih besar dibandingkan dengan panelis Ternate 7,43 dan Sidoarjo 7,34. Ekspresi hasil penilaian para panelis ini mencerminkan bahwa masyarakat Lamongan sebagai salah satu sentra penghasil ikan bandeng yang terbesar di Jawa Timur memberi apresiasi terhadap bandeng sebagai pilihan utama dalam konsumsinya. Pengolahan bandeng Lamongan untuk konsumsi sangat variatif dan mampu menjangkau area pemasaran yang sangat luas seperti: otak-otak, abon, presto, pindang, dan sebagainya. Selain itu, masyarakat Lamongan telah mampu menguasai pasar dan membentuk jaringan pasar yang luas ke kota-kota lain penghasil olahan bandeng seperti: Bandung, Jakarta, Semarang, dan Surabaya.

Produksi bandeng dari Ternate dan Halmahera Barat terkendala akses pasar yang terbatas hanya di sekitar Ternate; serta tersaingi oleh tingginya produk hasil perikanan tangkap karena perairan laut di Maluku Utara sangat kaya dengan potensi dan ragam ikan. Dengan demikian, ikan bandeng maupun produk olahannya bukan merupakan pilihan utama tatkala konsumen menghendaki untuk mengkonsumsi ikan, mempunyai banyak pilihan hasil perikanan. Hal yang sama dijumpai di 
Sidoarjo, juga banyak produk alternatif olahan makanan; meskipun bandeng dan udang merupakan simbol produk unggulan daerah ini.

\section{Nilai ekonomi cita rasa ikan bandeng}

Gormley (2013) menyebutkan bahwa nilai ekonomi ikan semakin tinggi, ditentukan oleh kandungan nutrisi yang bernilai fungsional. Susanto dan Fahmi (2012) menekankan nilai gizi utama terdapat pada protein, mineral, dan lemak. Ikan penghasil terbesar asam lemak dengan ikatan tak jenuh ganda PUFA (Polyunsaturated Fatty Acid) khususnya dalam bentuk EPA (Eicosapentanoic Acid) dan DHA (Docosahexanoic Acid).

Harakami toro dan sekami toro merupakan bagian tubuh ikan yang paling banyak mengandung lemak; memberikan cita rasa yang unggul terhadap ikan bandeng dibandingkan dengan ikan-ikan lainnya. Pada penyajian segar yang dimasak dengan berbagai variasi, maka bagian tubuh yang banyak mengandung lemak ini seyogyanya memiliki nilai yang lebih tinggi. Akan tetapi, pada umumnya konsumen dan penjual makanan menjajakan hasil masakannya dengan dasar pertimbangan ukuran besarnya potongan daging.

Nilai ekonomi produk juga dipengaruhi oleh persepsi konsumen terhadap produk itu sendiri. Asal usul ikan bandeng memiliki nilai ekonomi sebagai 'merek' (asal) yang mempengaruhi harga jualnya di pasar; dalam bentuk apapun, baik segar maupun olahan. Guna meningkatkan nilai ekonomi terhadap ikan bandeng yang dianggap berbau tanah, maka beberapa hal dapat dilakukan pada saat proses pasca panen maupun pengolahannya. Erungan (1997) menyarankan cara untuk menghilangkan bau lumpur ikan bandeng adalah dipelihara dulu di air tawar selama beberapa hari sebelum dikonsumsi; sedangkan Hafiludin dan Triajie (2011) melaporkan bahwa penambahan senyawa khitosan pada pakan ikan bandeng dapat memecah senyawa geosmin sehingga menurunkan cita rasa lumpur. Patang dan Yunarti (2014) memberikan pendapat lain bahwa penggaraman untuk membuat ikan bandeng sebagai ikan kering juga dapat menghilangkan pengaruh bau lumpur pada daging ikan.

Bau lumpur pada ikan bandeng dipengaruhi oleh habitat hidupnya. Perairan yang cenderung semakin tawar (salinitas rendah) diduga kuat menjadi habitat ganggang hijau biru (cyanobacter) yang dapat menghasilkan bau lumpur. Selain itu, residu kimia penggunaan pupuk anorganik berlebihan pada sawah tambak juga merupakan pemicu pesatnya pertumbuhan ganggang hijau biru tersebut. Houle, et al. (2011) melaporkan bahwa bau tidak enak seperti lumpur pada ikan hasil budidaya disebabkan oleh geosmin atau 2methylisorborneol (MIB) yang terdapat pada daging ikan. Senyawa ini bersifat semi volatile dalam air dan dapat terserap pada daging dan jaringan tubuh ikan lain yang kaya lemak. Cyanobacter dan actinomycetes merupakan genera yang banyak memproduksi kedua senyawa tersebut. Asquith (2015) dan Jiang, et al. (2007) menegaskan bahwa Streptomycetes coelicolor merupakan salah satu bakteri tanah yang menghasilkan geosmin dari enzim farnesyl diphosphate (FPP, 2) yang terkandung dalam tubuhnya.

Syifa, dkk. (2013), Susanto (2010) dan Vatria (2010) menegaskan bahwa ikan bandeng merupakan ikan yang sangat digemari. Pengolahan ikan bandeng dengan berbagai cara seperti: duri lunak, cabut duri, abon, bakso ikan, dan sebagainya sangat laku di pasaran dan telah memiliki konsumen yang loyal terhadap produk tersebut.

Berdasarkan hasil uji komparasi cita rasa ikan bandeng dari beberapa 
lokasi asal usul yang berbeda-beda; menunjukkan bahwa upaya petani tambak dan petani sawah tambak untuk menghilangkan atau meminimalisir bau lumpur pada daging ikan sudah memberikan hasil yang baik. Hasil penilaian organoleptik yang ditelusuri lebih mendalam melalui wawancara tertutup menunjukkan bahwa semua lokasi asal usul ikan bandeng yang diuji komparasi tidak ditemukan adanya daging yang mengandung bau tanah.

\section{KESIMPULAN}

\section{Kesimpulan}

Ikan bandeng Sidoarjo dianggap memiliki cita rasa yang paling enak dengan skor rata-rata 7,8; meskipun panelis di Sidoarjo menyatakan bahwa ikan bandeng yang berasal dari Cirebon memiliki cita rasa lebih enak.

Ikan bandeng Gresik dan Lamongan memiliki cita rasa yang terendah; beberapa konsumen mengaku masih ada cita rasa lumpur pada dagingnya. Guna memperoleh cita rasa yang tinggi, maka pengolahan menjadi berbagai macam produk turunan adalah cara penting untuk untuk meningkatkan nilai nutrisi, nilai gizi, dan nilai ekonomi.

\section{Rekomendasi}

Ikan bandeng asal Banyuwangi, Ternate, Gresik dan Lamongan seyogyanya lebih dikembangkan untuk produksi olahan, dibandingkan konsumsi dalam bentuk ikan segar. Pengolahan ikan bandeng direkomendasikan dalam bentuk produk turunan seperti: snack (kue kering), crackers (kerupuk), dan sejenisnya yang memiliki daya awet tinggi dan kaya fortifikasi bahan pangan lainnya.

Pembudidayaan ikan bandeng di air tawar, terlebih lagi pada sawah tambak seyogyanya petani secara berkala melakukan sirkulasi air untuk mengurangi pertumbuhan ganggang biru hijau yang dapat menghasilkan senyawa bau lumpur; agar cita rasa spesifik tetap terjaga. Perlakuan ini masih memenuhi skala ekonomi bagi petani karena nilai jual ikan bandeng yang dapat dipanen masih lebih tinggi apabila dibandingkan dengan nilai jual gabah.

\section{UCAPAN TERIMAKASIH}

Disampaikan kepada para petani tambak, penyuluh perikanan dan para sejawat akademisi lainnya yang telah membantu terwujudnya penelitian empiris; sebagai wujud (gambaran) nyata dinamika selera konsumen dan pemasaran ikan bandeng pada beberapa wilayah di Indonesia.

\section{DAFTAR PUSTAKA}

Asquith, E.A. 2015. Streptomyces as a Source of Geosmin and 2methylisoborneol Associated Taste and Odour Episodes in Drinking Water Reservoirs. University of Newcastle, Australia.

Datta, S. 2013. Rigor Mortis and Fish Spoilage. Training Manual on Fish Processing \& Value Added Fish Products. Central Institute of Fisheries Education, Mumbai. India.

Erungan, A.C. 1997. Geosmin Sebagai Penyebab Citarasa Lumpur Pada Ikan Serta Kemungkinan Penanggulangannya. Buletin Teknologi Hasil Perikanan. 4(2).

Gormley, R. 2013. Fish as a Functional Food: Some Issues and Outcomes. Supplement to Sea Health - ucd Issue 9. UCD Institute of Food and Health. University College Dublin. Ireland.

Hafiluddin, dan Triajie, H. 2011. Penambahan Khitosan Pada 
Pakan Ikan Bandeng (Chanos chanos) Sebagai Penurun Cita Rasa Lumpur (Geosmine). Jurnal Embryo. 8(20).

Houle, S., Schrader, K.K., Francois, N.R., Comeau, Y, Kharoune, M., Summerfelt, S.T., Savoie, A., and Vandenberg, G.W. 2011. Geosmin Causes Off Flavor in Arctic Charr in Recirculating Aquaculture Systems. Journal Aquaculture Research. 42.

Jiang, J., He, X, and Cane, D.E. 2007. Biosynthesis of The Earthy Odorant Geosmin by a Bifunctional Streptomyces coelicolor Enzyme. National Chemical Biology. 3(11).

Mchazime, I., and Kapute, F. 2018. Sensory and Nutrient Quality of Wild Capture Oreochromis shiranus (Boulenger, 1897) Stored at Ambient Temperatur. International Food Research Journal 25(1).

Patang, dan Yunarti. 2014. Kajian Pemberian Berbagai Dosis Garam Terhadap Kualitas Ikan Bandeng (Chanos chanos F.) Asin Kering. Jurnal Galung Tropika. 3(3).

Salitus, Ilminingtyas, D.W.H., dan Fatarina, E.P. 2017. Penambahan Tepung Tulang Bandeng (Chanos chanos) Dalam Pembuatan
Kerupuk Sebagai Hasil Samping Industri Bandeng Cabut Duri. Serat Acitya - Jurnal Ilmiah UNTAG Semarang. 6(2).

Susanto, E. 2010. Pengolahan Ikan Bandeng (Chanos chanos F.) Duri Lunak. Bahan penyuluhan masyarakat pesisir di Kabupaten Batang 27-28 Juli. Fakultas Perikanan dan Ilmu Kelautan Universitas Diponegoro. Semarang.

Susanto, E., dan Fahmi, A.S. 2012. Senyawa Fungsional Dari Ikan: Aplikasinya Dalam Pangan. Jurnal Aplikasi Teknologi Pangan. 1(4).

Syifa, N., Bintari, S.H., dan Mustikaningtyas, D. 2013. Uji Efektivitas Ekstrak Bawang Putih (Allium sativum L.) Sebagai Anti Bakteri Pada Ikan Bandeng (Chanos chanos F.) Segar. Unnes Journal Of Life Science. 2(2).

Tilami, S.K., and Sampels, S. 2017. Nutritional Value of Fish: Lipids, Proteins, Vitamins, and Minerals. Review in Fisheries Science \& Aquaculture.

Vatria, B. 2012. Pengolahan Ikan Bandeng (Chanos chanos) Tanpa Duri. Jurnal Ilmu Pengetahuan dan Rekayasa. 